\title{
Anti-Candida properties of asaronaldehyde of Acorus gramineus rhizome and three structural isomers
}

\author{
Sandeep B Rajput, Ravikumar B Shinde, Madhushree M Routh and Sankunny M Karuppayil
}

\begin{abstract}
Background: Asaronaldehyde (2, 4, 5-trimethoxybeznaldehyde) is an active component of Acorus gramineus rhizome. This study aims to evaluate the anti-Candida efficacy of asaronaldehyde and its three structural isomers, namely, 2, 3, 4-trimethoxybenzaldehyde, 3, 4, 5-trimethoxybenzaldehyde, and 2, 4, 6- trimethoxybenzaldehyde.

Methods: Susceptibility testing of test compounds was carried out using standard methodology (M27-A2) as per clinical and laboratory standards institute guidelines. Minimum fungicidal concentration (MFC) was determined as the lowest concentration of drug killing $99.9 \%$ of Candida cells. The effect on sterol profile was evaluated using the ergosterol quantitation method. Effects on morphogenesis, adhesion and biofilm formation in C. albicans were studied using germ-tube, adherence and biofilm formation assays respectively. Cytotoxicity of test compounds to human RBCs was determined by hemolysis assay.

Results: 2, 4, 6-Trimethoxybenzaldehyde exhibited significant anti-Candida activity ( $P=0.0412$ ). Minimum inhibitory concentration (MIC) and minimum fungicidal concentration (MFC) were established as 0.25 and $0.5 \mathrm{mg} / \mathrm{mL}$, respectively. All of the test compounds showed significant inhibition of hyphal form transition in yeast at MIC/2 and MIC/4 values. 3, 4, 5-Trimethoxybenzaldehyde and 2, 4, 6-trimethoxybenzaldehyde inhibited adhesion and biofilms. A hemolytic assay of these compounds revealed that they were non-toxic at MIC values. Asaronaldehyde reduced sterol content.
\end{abstract}

Conclusion: Asaronaldehyde and 2, 4, 6-trimethoxybenzaldehyde showed anti-Candida efficacy.

\section{Background}

Drug resistant pathogens and serious side effects are major problems in antifungal chemotherapy [1]. Candida species are the fourth leading cause of nosocomial bloodstream infections in the United States, with treatment costs estimated to be more than two to four billion US dollars annually [2] and with attributable mortality rates estimated to be $38-49 \%$ [3]. Candida albicans is a ubiquitous organism in humans and causes serious disseminated infections in the immunocompromised population [4]. It colonizes and forms biofilms on host tissues and indwelling prosthetic devices [5]. Biofilms are resistant to most of the available antibiotics, except echinocandins (e.g., caspofungin and micafungin) [6]. Several antifungal compounds have been developed, targeting diverse biological

* Correspondence: prof.karuppayil@gmail.com DST-FIST and UGC-SAP Sponsored School of Life Sciences, SRTM University, Nanded 431-606, MS, India pathways essential for fungal growth, e.g., the ergosterol synthesis pathway or its end product ergosterol [7]. Unfortunately, most of the available antifungals have side effects, such as nephrotoxicity (amphotericin B) and gastrointestinal intolerance (Fluconazole), and drug resistance has developed [8-10]. The emergence of drug resistance and serious side effects suggest the need for new and safer antifungals.

Chinese and Korean pharmacopoeias have demonstrated sedative, digestive, analgesic, diuretic and antifungal actions of extracts of Acorus gramineus [11-14]. Asaronaldehyde (2, 4, 5-trimethoxybeznaldehyde), an active principle of $A$. gramineus rhizomes, exhibits fungicidal activity against several phytopathogenic fungi [15]. Asaronaldehyde is a selective inhibitor of cyclooxygenase II (COX-II) [16], consisting of a benzene ring substituted with aldehyde and methoxy groups. Aromatic compounds bearing a trimethoxy group are known to exhibit

\section{Biomed Central}


good antibacterial and antifungal activities [17]. However, structurally related compounds differ in their bioactivities, and the difference in the conformation and position of the functional group(s) determines their binding affinity to target molecules and clinical efficacy $[18,19]$. To our knowledge, the effects of asaronaldehyde and its structural isomers, namely, 2, 3, 4-trimethoxybenzaldehyde, 3, 4, 5-trimethoxybenzaldehyde, and 2, 4, 6trimethoxybenzaldehyde (Figure 1), on the human pathogenic yeast $C$. albicans, have not been reported. However, alpha and beta asarones are known to exhibit anti-C. albicans activity [20].

This study aimed to investigate the anti-Candida efficacy and mechanism of action of asaronaldehyde and its structural isomers.

\section{Methods}

Media, chemicals and culture conditions

The C. albicans ATCC 90028 (MTCC 3017) strain was obtained from the Institute of Microbial Technology (Chandigarh, India), and was maintained on Yeast-Peptone-Dextrose (YPD) agar slants at $4^{\circ} \mathrm{C}$. RPMI-1640 medium (with L-glutamine and without sodium bicarbonate), 3-[N-morpholine] propane sulfonic acid (MOPS), Sabourauds dextrose broth (SDB), YPD media and 3-(4, 5dimethylthiazol-2-yl)-2, 5-diphenyltetrazolium bromide (MTT) were purchased from Hi-Media Laboratories Ltd.

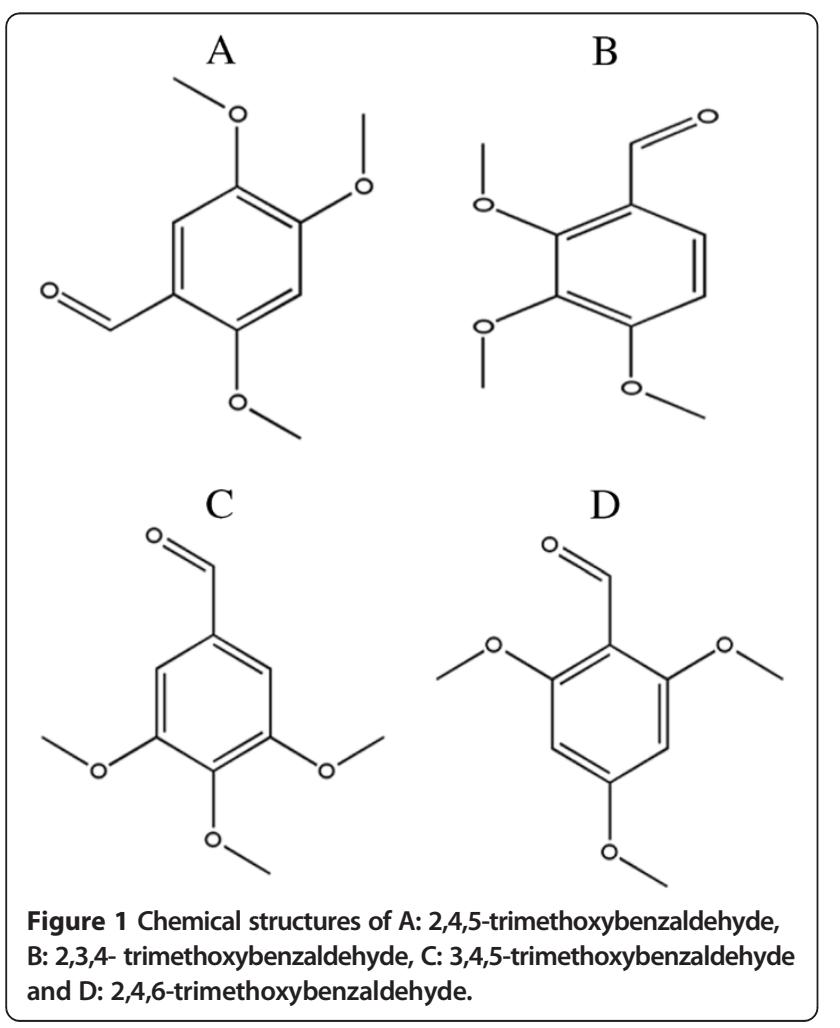

(Mumbai, India). Triton-X 100 was purchased from Qualigens Fine Chemicals Pvt. Ltd. (India). 2, 4, 5-Trimethoxybenzaldehyde (asaronaldehyde or asaraldehyde), 2, 3, 4-trimethoxybenzaldehyde, 3, 4, 5-trimethoxybenzaldehyde, and 2, 4, 6-trimethoxybenzaldehyde were purchased from Thermo Fisher Scientific (Acros Organics), Pvt. Ltd. (India).

\section{Growth assay}

The susceptibility study was carried out using the microbroth dilution method as per clinical and laboratory standards institute (CLSI) guidelines [21]. Various concentrations of the test compounds $(0.0156 \mathrm{mg} / \mathrm{mL}$ to $8 \mathrm{mg} / \mathrm{mL}$ ) were prepared in RPMI-1640 medium by double dilution in 96-well plates. Each well contained an inoculum of $1 \times 10^{3}$ cells $\mathrm{mL}^{-1}$ and the final volume of RPMI-1640 medium maintained in each well was $200 \mu \mathrm{L}$. Wells without addition of compounds served as a control. Microplates were incubated at $35^{\circ} \mathrm{C}$ for $48 \mathrm{~h}$ and read spectrophotometrically at $620 \mathrm{~nm}$ using a microplate reader (Multiskan EX, Thermo Electron Corp. USA). The minimum inhibitory concentration (MIC) was considered to be the minimum concentration required to produce a $50 \%$ reduction in absorbance.

\section{Viability assay}

Cells from the MIC and the wells above were selected to determine the minimum candidacidal concentrations of the test compounds. An aliquot of $10 \mu \mathrm{L}$ of cell suspension from each well was spread on YPD agar plates. The plates were incubated for $24 \mathrm{~h}$ at $30^{\circ} \mathrm{C}$ and observed for the presence of colonies. Minimum fungicidal concentration (MFC) was considered as the lowest concentration required to kill $99.9 \%$ of Candida cells [22].

\section{Hemolytic activity}

The hemolytic activities of the test compounds were determined using human red blood cells [23]. Human erythrocytes from healthy persons were collected in tubes containing EDTA $(1-2 \mathrm{mg} / \mathrm{ml})$ as anti-coagulant. The erythrocytes were harvested by centrifugation (Heraeus Megafuge 40, Thermo Fisher Scientific Inc., MA) for $10 \mathrm{~min}$ at $634 \times g$ at $20^{\circ} \mathrm{C}$, and washed three times in PBS. PBS was added to the pellet to yield a $10 \%$ (v/v) erythrocytes/PBS suspension. The $10 \%$ suspension was diluted 1:10 in PBS. From each suspension, $100 \mu \mathrm{L}$ was added in triplicate to $100 \mu \mathrm{L}$ of a different dilution series of test compounds (or fluconazole as a standard antifungal) in the same buffer in Eppendorf tubes. Total hemolysis was achieved using $1 \%$ Triton $\mathrm{X}-100$. The tubes were incubated for $1 \mathrm{~h}$ at $37^{\circ} \mathrm{C}$ and centrifuged for $10 \mathrm{~min}$ at $634 \times g$ at $20^{\circ} \mathrm{C}$. From the supernatant fluid, $150 \mu \mathrm{L}$ was transferred to a flat-bottomed microtiter plate (Tarson India Ltd., India), and the absorbance was 
measured at $450 \mathrm{~nm}$. Percent hemolysis was calculated using following equation:

$$
\begin{aligned}
& \% \text { Hemolysis } \\
& =\frac{\mathrm{A}_{450} \text { of test compound treated sample- } \mathrm{A}_{450} \text { of buffer treated sample }}{\mathrm{A}_{450} \text { of } 1 \% \text { Triton }-\mathrm{X} 100 \text { treated sample }-\mathrm{A}_{450} \text { of buffer treated sample) }} \\
& \quad \times 100 \%
\end{aligned}
$$

\section{Ergosterol extraction and quantitation assay}

A single colony of $C$. albicans from an overnight grown SDA plate culture was used to inoculate $50 \mathrm{~mL}$ of SDB containing various concentrations of different test compounds. SDB without test compound served as a control. The cultures were incubated for 16-18 h and harvested by centrifugation at $856 \times g$ for $5 \mathrm{~min}$. The net weight of the cell pellet was determined. Three milliliters of $25 \%$ alcoholic potassium hydroxide solution was added to the cell pellet and vortex mixed for $1 \mathrm{~min}$. Cell suspensions were transferred to sterile borosilicate glass screw-cap tubes and incubated in an $85^{\circ} \mathrm{C}$ water bath for $1 \mathrm{~h}$. Following incubation, the tubes were cooled. Sterols were extracted by addition of a mixture of $1 \mathrm{~mL}$ of sterile distilled water and $3 \mathrm{~mL}$ of $n$-heptane followed by vigorous vortex mixing for $3 \mathrm{~min}$. The heptane layer was transferred to a clean borosilicate glass screw-cap tube. Prior to analysis, a $0.6 \mathrm{~mL}$ aliquot of sterol extract was diluted five fold in 100\% ethanol and scanned between 240 and $300 \mathrm{~nm}$ using a spectrophotometer (UV-1800 Spectrophotometer, Shimadzu, Japan). Ergosterol content was calculated as a percentage of the wet weight of the cell [24].

\section{Germ tube formation assay}

Inhibition of in vitro germ tube formation by test compounds was studied using 96-well microtiter plates based on the method of Chauhan et al. [25]. Cells were inoculated in RPMI-1640 medium with various concentrations of test compounds to obtain $1 \times 10^{6}$ cells $/ \mathrm{mL}$. Wells without test compound were used as a control. The plates were incubated at $37^{\circ} \mathrm{C}$ with shaking at $200 \mathrm{rpm}$ on an orbital shaker for $3 \mathrm{~h}$, and cells were observed microscopically. Each time, 100 cells were counted and the numbers of yeast cells (budded or unbudded) and germ tubes formed were noted. The percentage of germ tube formation in each well compared with that in the control well was calculated.

\section{Adhesion assay}

The effects of the four test compounds on adherence of C. albicans to a polystyrene surface were studied based on the method of Camacho et al. [26]. In brief, $1 \times$ $10^{7}$ cells $/ \mathrm{mL}$ was allowed to adhere to the polystyrene surface of 96-well plates in the presence of various concentrations ranging from $0.0156 \mathrm{mg} / \mathrm{mL}$ to $2 \mathrm{mg} / \mathrm{mL}$ of the test compounds in PBS. Wells without test compound were used as controls. The plates were incubated at $37^{\circ} \mathrm{C}$ for $90 \mathrm{~min}$ at $100 \mathrm{rpm}$ on an orbital shaking incubator to allow cell attachment to the surface. After the incubation, wells were washed with PBS to remove non-adhered cells. The density of adherence in each well was analyzed using an MTT metabolic assay and the percentage of adhered cells was calculated and compared with that in control wells. MTT solution was prepared by mixing $1 \mathrm{mg} / \mathrm{mL}$ MTT salt in PBS and storing at $-20^{\circ} \mathrm{C}$.

\section{Biofilm formation assay}

C. albicans biofilms were developed on polystyrene surfaces of 96-well plates as per standard methodologies [27]. One hundred microliters of a cell suspension $\left(1 \times 10^{7}\right.$ cells $\left./ \mathrm{mL}\right)$ in PBS was inoculated and plates were incubated at $37^{\circ} \mathrm{C}$ for 90 min to allow attachment of cells onto the surface. Non-adhered cells were removed by washing the wells with sterile PBS, two to three times. RPMI-1640 medium $(200 \mu \mathrm{L})$ was added to each well and the plates were incubated at $37^{\circ} \mathrm{C}$ for $24 \mathrm{~h}$ to allow biofilm formation. RPMI-1640 medium with various concentrations of test compound was added immediately after the adhesion phase to observe any effects on the development of biofilms. After incubation, wells were washed to remove any released cells, and biofilms were observed under an inverted light microscope (Metzer, India). Biofilm growth was analyzed by MTT-metabolic assay.

\section{Biofilm quantitation by MTT assay}

Biofilm growth was quantified by MTT metabolic assay [27]. Wells containing biofilms were washed with PBS to remove non adhered cells and incubated for $5 \mathrm{~h}$ in $100 \mu \mathrm{L}$ of MTT solution in the dark. After incubation, unbound MTT was replaced with $150 \mu \mathrm{L}$ of DMSO (100\%) for 2 to 3 min. Treated samples $(100 \mu \mathrm{L})$ were then taken into new wells. Color formation was measured at $450 \mathrm{~nm}$ using a microplate reader (Multiskan EX, Thermo Electron Corp. USA). Wells without test compounds were used as controls, while those without biofilms were the blanks.

\section{Scanning electron microscopy (SEM) of C. albicans biofilms}

Candida biofilms were developed by seeding silicon discs with $2 \mathrm{~mL}$ of standardized cell suspension of $1 \times 10^{7}$ cells/ $\mathrm{mL}$ into 12 -well plates. The plates were incubated at $37^{\circ} \mathrm{C}$ at $50 \mathrm{rpm}$ for $90 \mathrm{~min}$. Non-adhered cells were removed by washing the discs with PBS 2-3 times. RPMI-1640 medium along with $2,4,6-\mathrm{TMB}(0.5 \mathrm{mg} / \mathrm{mL})$ and one control without 2, 4, 6-TMB was added to each well. The final volume of the assay system in each well was kept to $3 \mathrm{~mL}$. The plate was incubated at $37^{\circ} \mathrm{C}$ for $24 \mathrm{~h}$ to allow biofilm formation. After incubation, discs were washed to remove any planktonic cells. For SEM, samples were fixed 


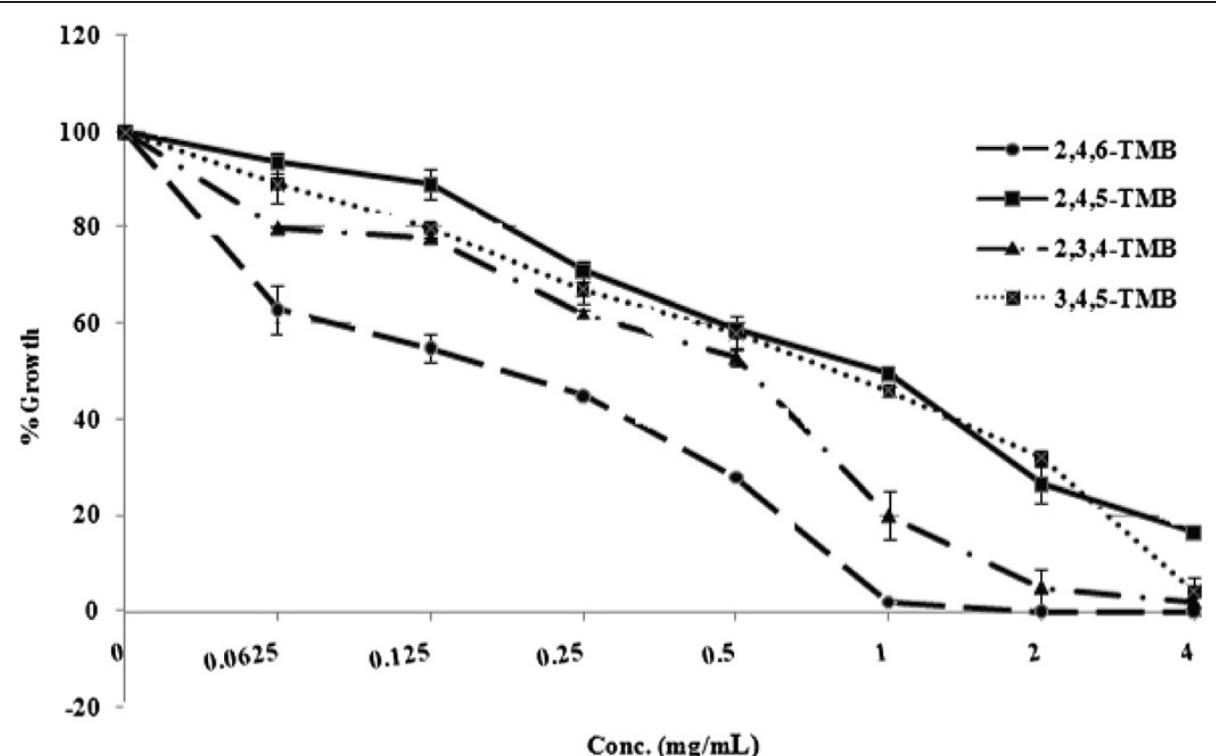

Figure 2 Effects of 2,4,5-trimethoxybenzaldehyde; 2,3,4-trimethoxybenzaldehyde; 3,4,5-trimethoxybenzaldehyde and 2,4,6-trimethoxybenzaldehyde on the growth of C. albicans ATCC 90028.

in $2.5 \%$ of glutaraldehyde $(0.1 \mathrm{~mol} / \mathrm{L})$ in phosphate buffer $(\mathrm{pH} 7.2)$ for $24 \mathrm{~h}$ at $4^{\circ} \mathrm{C}$. Samples were postfixed in a $2 \%$ aqueous solution of osmium tetraoxide for $4 \mathrm{~h}$, then dehydrated in a series of graded alcohols and finally dried to a critical drying point with a Critical Point Dryer unit. The samples were mounted over stubs and gold coating was performed by an automated gold coater (Model: JOEL JFC-1600, JOEL Limited, Akishima, Tokyo 1960022, Japan) for $3 \mathrm{~min}$. Photos were taken under a scanning electron microscope (Model: JOEL JSM 7600F, JOEL Limited, Akishima, Tokyo 1960022, Japan) [25].

\section{Statistical analysis}

Values are presented as the means of triplicate observations \pm standard deviation (SD). Percentage growth in the presence of test compounds and in controls was analyzed by Student's $t$ test (GraphPad prism 5.0 software, USA), and $P<0.05$ was considered statistically
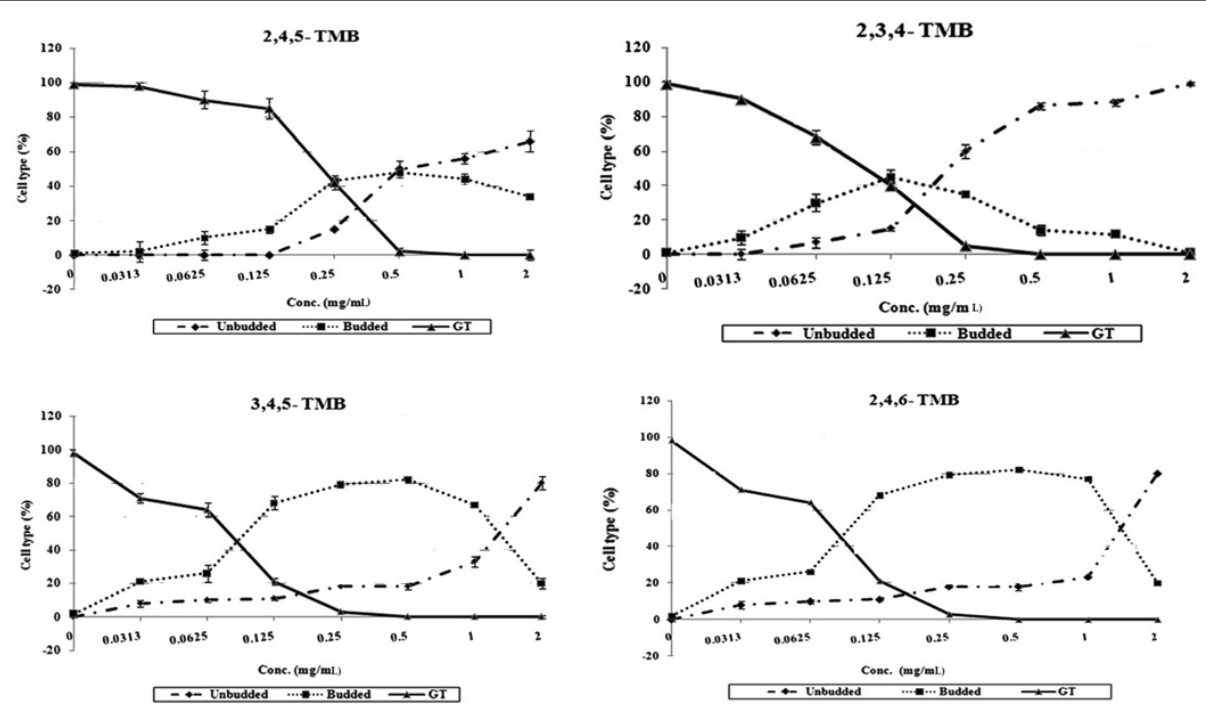

Figure 3 Effects of 2,4,5-trimethoxybenzaldehyde; 2,3,4-trimethoxybenzaldehyde; 3,4,5-trimethoxybenzaldehyde and 2,4,6-trimethoxybenzaldehyde on RPMI-1640-induced germ tube formation in C. albicans ATCC 90028. 


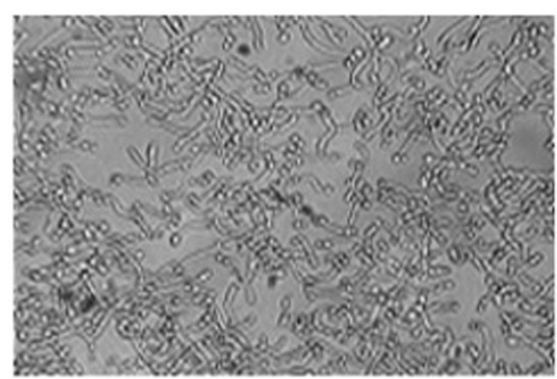

A

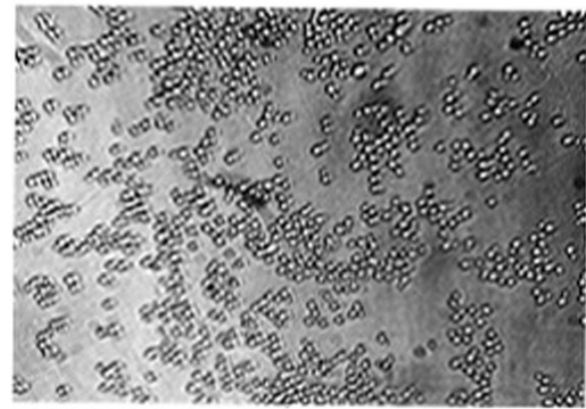

B

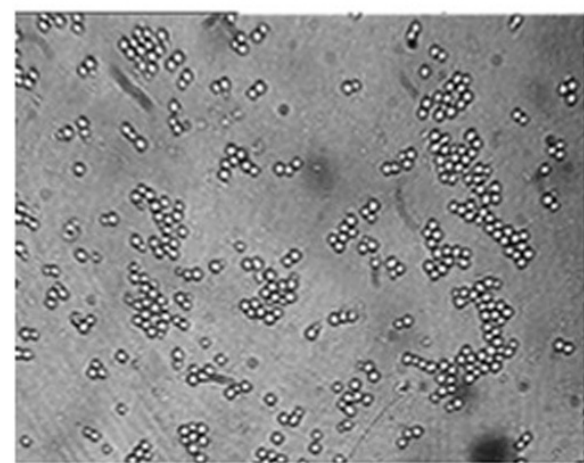

D

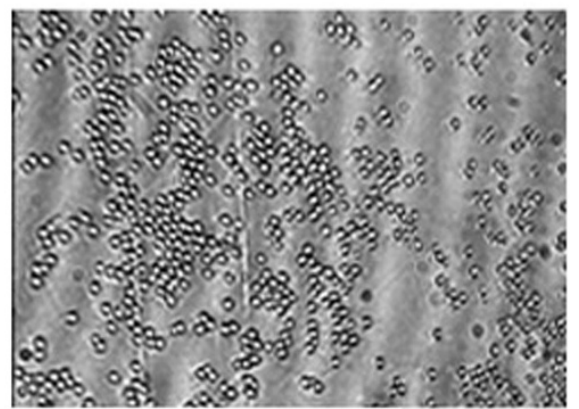

$\mathrm{C}$

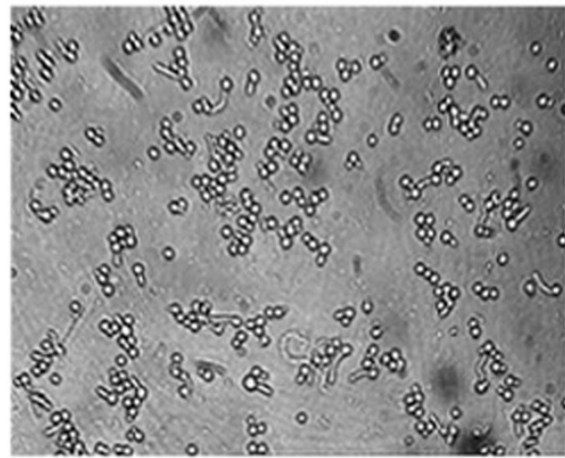

$\mathrm{E}$

Figure 4 Germ tube formation of C. albicans ATCC 90028 in the absence of the test compound (A) and in the presence of an MIC/2 concentration of 2,4,5-trimethoxybenzaldehyde (B), 2,3,4-trimethoxybenzaldehyde (C), 3,4,5-trimethoxybenzaldehyde and (D) 2,4,6-trimethoxybenzaldehyde (E).

significant. The concentration-dependent manner of any effect was visually determined.

\section{Results and discussion}

The compounds tested in this study, which differ only in terms of the conformation or position of methoxy groups, showed various degrees of antifungal activity. All of the compounds significantly $(P=0.0412$ for 2 , 4, 5-trimethoxybenzaldehyde, $P=0.0454$ for 2,4 , 5-trimethoxybenzaldehyde, $P=0.0490$ for 2,3 , 4trimethoxybenzaldehyde, $P=0.0475$ for $3,4,5$-trimethoxybenzaldehyde) inhibited planktonic growth of C. albicans in a concentration-dependent manner. 2, 4, 6trimethoxybenzaldehyde inhibited the growth and viability of C. albicans at 0.25 and $1 \mathrm{mg} / \mathrm{mL}$, respectively, while 2 ,

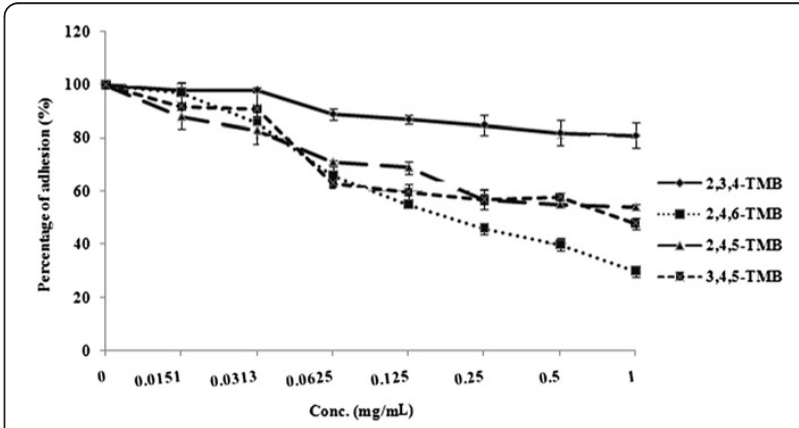

Figure 5 Effects of 2,4,5-trimethoxybenzaldehyde; 2,3,4-trimethoxybenzaldehyde; 3,4,5-trimethoxybenzaldehyde and 2,4,6-trimethoxybenzaldehyde on adhesion in C. albicans ATCC 90028 . 


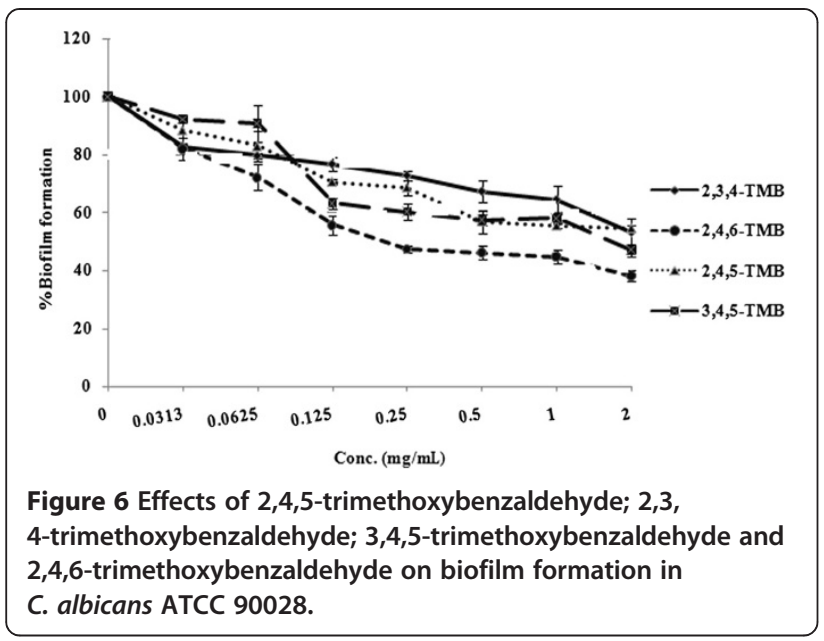

4, 5-trimethoxybenzaldehyde, 2, 3, 4-trimethoxybenzaldehyde and 3, 4, 5-trimethoxybenzaldehyde showed MIC at $1 \mathrm{mg} / \mathrm{mL}$ (Figure 2). The MFC of 2, 3, 4-trimethoxybenzaldehyde was $2 \mathrm{mg} / \mathrm{mL}$, whereas the MFCs for 2, 4, 5-trimethoxybenzaldehyde and 3, 4, 5-trimethoxybenzaldehyde were 8 and $4 \mathrm{mg} / \mathrm{mL}$, respectively.

Complete inhibition of Candida growth by the four compounds was observed at sub-inhibitory concentrations (Figure 3) ( $P=0.0402$ for 2, 4, 5-trimethoxybenzaldehyde, $P=0.0410$ for $2,4,5$ - trimethoxybenzaldehyde, $P=0.0480$ for 2, 3, 4-trimethoxybenzaldehyde, and $P=0.0497$ for 3, 4, 5-trimethoxybenzaldehyde). All four compounds inhibited $80-100 \%$ of the yeast to hyphal transition at sub-inhibitory concentrations $(P=0.0353$ for 2,4 , 5-trimethoxybenzaldehyde, $P=0.0301$ for $2,4,5$ trimethoxybenzaldehyde, $P=0.0390$ for 2 , 3, 4-trimethoxybenzaldehyde, and $P=0.0405$ for 3,4 , 5 -trimethoxybenzaldehyde). In addition to germ tube inhibition, inhibition of budding was also recorded (Figures 3 and 4). A greater than $50 \%$ of reduction in morphogenesis was observed at $0.125 \mathrm{mg} / \mathrm{mL}$ for 2, 3, 4-trimethoxybenzaldehyde, 3, 4, 5-trimethoxybenzaldehyde and 2, 4, 6-trimethoxybenzaldehyde, while similar results were observed at $0.25 \mathrm{mg} / \mathrm{mL}$ for 2, 4, 5-trimethoxybenzaldehyde. Inhibiting virulence factors, e.g., dimorphism, without killing the pathogen, might avoid natural selection and thereby prevent the emergence of a drug-resistant population.

Adhesion is an early stage of biofilm development which is important for Candida colonization and infection [5]. The compounds 3, 4, 5-trimethoxybenzaldehyde and 2, 4, 6-trimethoxybenzaldehyde significantly inhibited biofilm development in $C$. albicans $(P=0.050$ for 3,4 , 5trimethoxybenzaldehyde, and $P=0.0495$ for $2,4,6$-trimethoxybenzaldehyde) (Figures 5 and 6). These compounds prevented more than $50 \%$ of adhesion at their MIC values ( $P=0.0481$ for 3, 4, 5-trimethoxybenzaldehyde, and $P=$ 0.0395 for 2, 4, 6-trimethoxybenzaldehyde). The compound 2, 4, 5-trimethoxybenzaldehyde showed a $46 \%$ reduction in adhesion at $1 \mathrm{mg} / \mathrm{mL}(P=0.05)$. However, 2, 3, 4-trimethoxybenzaldehyde did not have a considerable effect on the adhesion of $C$. albicans yeast-phase cells $(P=0.0481)$; only $19 \%$ inhibition of adhesion was observed at MIC (Figure 5).

Biofilms are resistant to antifungal antibiotics, including the most commonly prescribed drug, fluconazole $[5,28]$. All of the compounds tested significantly inhibited biofilm formation, even at their MIC values. The MIC for prevention of biofilm formation for 3, 4, 5-trimethoxy-benzaldehyde and 2, 4, 6-trimethoxybenzaldehyde was achieved at the MIC for inhibition of growth $(P=0.05$ for 3,4 , 5-trimethoxybenzaldehyde, and $P=0.0495$ for $2,4,6$ trimethoxybenzaldehyde). Addition of $1 \mathrm{mg} / \mathrm{mL} \mathrm{2,} \mathrm{4,}$ 5-trimethoxybenzaldehyde and 2, 3, 4-trimethoxybenzaldehyde immediately after the adhesion phase caused $45 \%$ and $35 \%$ inhibition of biofilm formation, respectively $(P=0.0377$ for 2, 4, 5-trimethoxybenzaldehyde, and

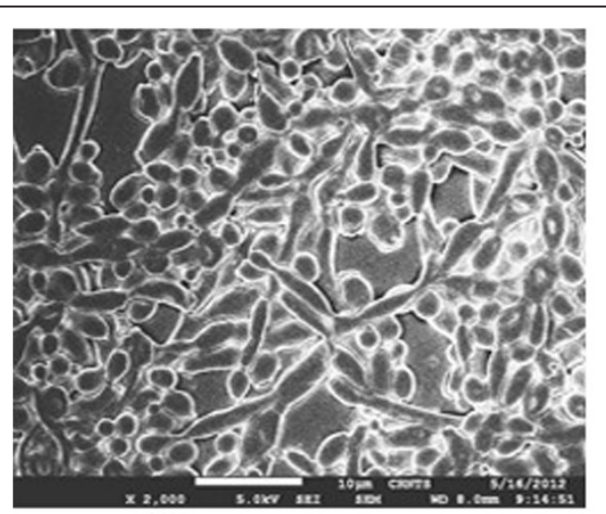

A

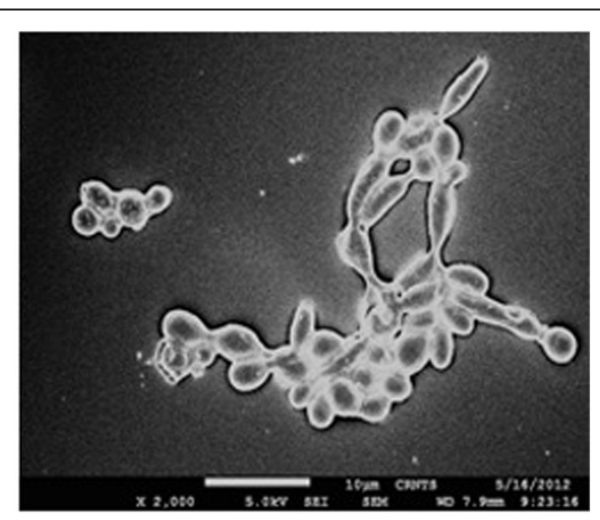

B

Figure 7 Scanning electron micrograph (at magnification $\times 2000$ ) of a Candida albicans biofilm in the absence $(A)$ and presence $(B)$ of $2 \times$ MIC of 2, 4, 6-trimethoxybenzaldehyde. 
$P=0.0475$ for 2, 3, 4-trimethoxybenzaldehyde) (Figure 6). The ultrastructure of untreated $C$. albicans biofilms exhibited a dense cell network of yeasts, budding yeasts and hyphae. Treatment with 2, 4, 6-trimethoxybenzaldehyde significantly reduced cell density with few budded and hyphal forms (Figure 7).

The in vitro hemolytic assay is a screening tool for gauging in vivo toxicity toward host cells [29]. The four compounds tested showed no significant toxicity to human erythrocytes at minimum growth inhibitory concentrations $(P=0.0303$ for $2,4,5$-trimethoxybenzaldehyde, $P=0.0331$ for $2,4,5$-trimethoxybenzaldehyde, $P=0.0396$ for 2, 3, 4-trimethoxybenzaldehyde, and $P=0.040$ for 3, 4, 5 -trimethoxybenzaldehyde), whereas they had profound effects on dimorphism, adhesion and biofilm formation by C. albicans (Figure 8). Only $0-12 \%$ hemolysis was observed at the tested concentrations, while fluconazole showed $100 \%$ hemolysis at $0.5 \mathrm{mg} / \mathrm{mL}$.

COX-dependent pathways may be responsible for the prostaglandin (PGE2) synthesis in C. albicans, and prostaglandin induces pathogenicity in C. albicans [30,31]. COX-II inhibitors inhibit morphogenesis and biofilm formation in C. albicans [32]. There is controversy about whether COX inhibitors affect filamentation by blocking prostaglandin synthesis and, moreover, it is known that C. albicans does not encode a COX homolog. Asaronaldehyde is a selective COX II inhibitor [33], and

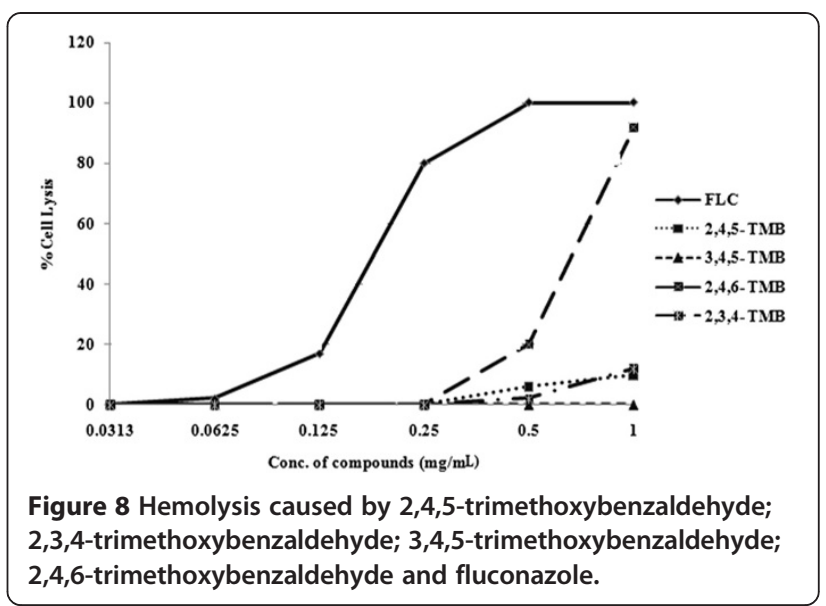

was found to inhibit yeast to hyphal transition and biofilm formation in this study.

In our study, asaronaldehyde inhibited sterol biosynthesis. As shown in Figure 9, the average decreases in total cellular ergosterol content of Candida cells after exposure to their respective $\mathrm{MIC}, \mathrm{MIC} / 2, \mathrm{MIC} / 4$, $\mathrm{MIC} / 8$ and $\mathrm{MIC} / 16$ of 2, 4, 5-trimethoxybenzaldehyde were $92 \%, 47 \%, 25 \%, 10 \%$ and $0 \%$ respectively $(P=$ 0.0453 for 2, 4, 5-trimethoxybenzaldehyde, $P=0.0406$ for 2, 4, 5-trimethoxybenzaldehyde, $P=0.0397$ for 2,3 , 4-trimethoxybenzaldehyde, and $P=0.0485$ for 3,4 ,

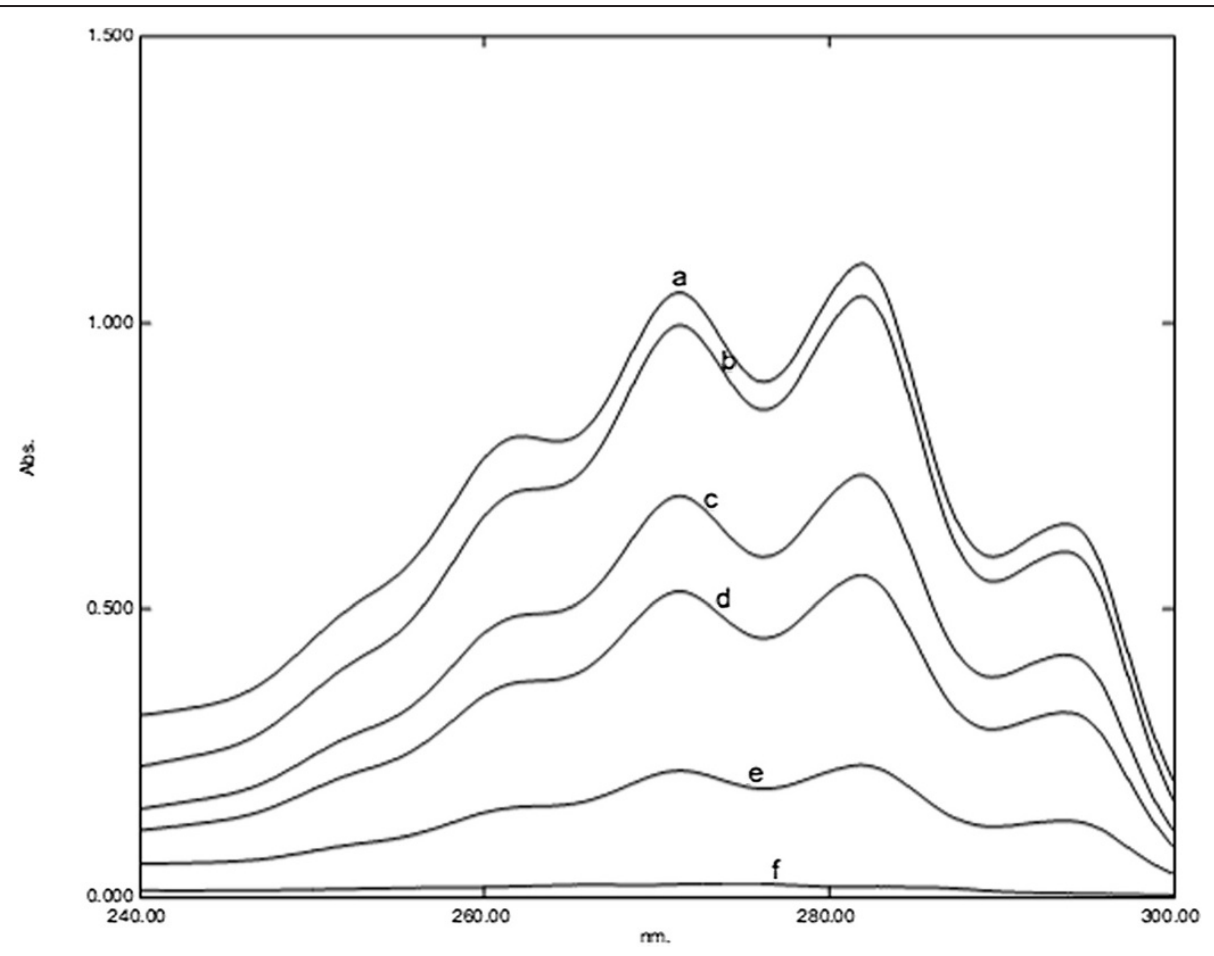

Figure 9 UV spectrophotometric sterol profile of C. albicans ATCC 90028, treated with 0 (curve a), 0.0625 (curve b), 0.125 (curve c), 0.25 (curve d), 0.5 (curve e) and 1 (curve f) $\mathrm{mg} / \mathrm{mL}$ of asaronaldehyde (2,4,5- trimethoxybenzaldehyde). 
5-trimethoxybenzaldehyde). Other compounds did not show any effect on ergosterol biosynthesis. Additionally, beta-asarone, which is closely related to asaronaldehyde, inhibits ergosterol biosynthesis in C. albicans [34].

\section{Conclusion}

Asaronaldehyde and 2, 4, 6-trimethoxybenzaldehyde showd anti-Candida efficacy.

\section{Abbreviations \\ COX: Cyclooxygenase.}

\section{Competing interests}

The authors declare that they have no competing interests.

\section{Authors' contributions}

KSM conceived the study. SBR and RS performed the experiments. SBR and MMR wrote the manuscript. All authors read and approved the final version of the manuscript.

\section{Acknowledgements}

SBR is thankful to DST, New Delhi, for providing DST-INSPIRE fellowship Ref No. DST/INSPIRE FELLOWSHIP/2010/(290). We are thankful to Prof. S. B. Nimse, the Honorable Vice Chancellor of SRTM University, for his kind support.

Received: 15 October 2012 Accepted: 3 September 2013 Published: 8 September 2013

\section{References}

1. Afeltra J, Verwrji PE: Antifungal activity of non-antifungal drugs. Eur J Clin Microbiol Infect Dis 2003, 22:397-407.

2. Wilson LS, Reyes CM, Stolpman M, Speckman J, Allen K: The direct cost and incidence of systemic fungal infections. Value Health 2002, 5:26-34.

3. Gudlaugsson O, Gillespie S, Lee K, Vande Berg J, Allen K: The direct cost and incidence of systemic fungal infections. Value Health 2003, 37:1172-1177.

4. Kim J, Sudbery P: Candida albicans, a major human fungal pathogen. The J Microbiol 2011, 49:171-172.

5. Ramage G, Saville SP, Thomas DP, Lopez-Ribot JL: Candida biofilms: an update. Eukar Cell 2005, 4:633-638.

6. Cateau E, Rodier MH, Imbert C: In vitro efficacies of caspofungin or micafungin catheter lock solutions on Candida albicans biofilm growth. J Antimicrob Chemother 2008, 62:153-155.

7. Sanglard D, Ischer F, Parkinson T, Falconer D, Bille J: Candida albicans mutations in the ergosterol biosynthetic pathway and resistance to several antifungal agents. Antimicrob Agents Chemother 2003, 47:2404-12.

8. Cannon RD, Lamping E, Holmes AR, Niimi K, Baret PV, Keniya MV, Tanabe K, Niimi M, Goffeau A, Monk BC: Efflux-mediated antifungal drug resistance. Clin Microbiol Rev 2009, 22:291-321.

9. Odds FC, Brown AJ, Gow NA: Antifungal agents: mechanisms of action. Trends Microbiol 2003, 11(6):272-279.

10. Gupta AK, Tomas E: New antifungal agents. Dermatol Clin 2003, 21:565-76.

11. Chang HH, But PPH: Pharmacology and Applications of Chinese Martera Medica, Volume 1. Singapore: World Scientific Publisher; 1986:334-337.

12. Namba T: The encyclopedia of Wakan-Yuku (tranditional Sino Japanese Medicines, with color pictures), Volume 1. Japan: Hoikusha; 1993:606.

13. Tang W, Eisenbrand G: Chinese Drugs of Plant Origin. New York: Springer; 1992:45-46.

14. Wang HZ, Cheng YG, Fan CS: Review of studies on chemical constituents and pharmacology of genus Acorus. Acta Bot Yunnanica 1998, 10:96-100.

15. Lee HS: Fungicidal property of active component derived from Acorus greamineus rhizome against phytopathogenic fungi. Bioresource Technol 2007, 98:1324-1328.

16. Momin RA, DeWitt DL, Nair MG: Inhibition of cyclooxygenase (COX) enzymes by compounds from Daucus carota L. seeds. Phytother Res 2003, 17:976-979.

17. Kumar S, Niranjan MS, Chaluvaraju KC, Jamakhandi CM, Kadadevar D: Synthesis and antimicrobial study of some Schiff bases of sulfonamides. J Cur Pharm Res 2010, 1:39-42.
18. Ahmed A, Akhtar A, Yousuf S, Xess I, Khan LA, Manzoor N: Fungicidal activity of thymol and Carvacrol by disrupting ergosterol biosynthesis and membrane integrity against Candida. Eur J Clin Microbiol Infect Dis 2011, 30:41-50.

19. Medina-Franco JL, Lopez-Vallejo F, Rodriguez-Morales S, Castillo R, Chamorro G, Tamariz J: Molecular docking of the highly hypolipidemic agent á-asarone with the catalytic portion of HMG-CoA reductase. Bioorg Med Chem Lett 2005, 15:989.

20. Devi SA, Ganjewala D: Antimicrobial activity of Acorus calamus (L.) rhizome and leaf extract. Acta Biol Szegediensis 2009, 53:45-49.

21. Rajput SB, Karuppayil SM: Small molecules inhibit growth, viability and ergosterol biosynthesis in Candida albicans. SpringerPlus 2013, 2:26.

22. Zore GB, Thakre AD, Jadhav S, Karuppayil SM: Terpenoids inhibit Candida albicans growth by affecting membrane integrity and arrest of cell cycle. Phytomed 2011, 8:1181-1190

23. Ahmad A, Khan A, Manzoor N, Khan LA: Evolution of ergosterol biosynthesis inhibitors as fungicidal against Candida. Microb Pathog 2010, 48:35-41.

24. Arthington-Skaggs BA, Jradi H, Desai T, Morrison CJ: Quantification of ergosterol content: novel method for determination of Fluconazole susceptibility of Candida albicans. J Clin Microbiol 1999, 37:3332-3337.

25. Chauhan NM, Raut JS, Karuppayil SM: A morphogenetic regulatory role for ethyl alcohol in Candida albicans. Mycoses 2011, 54:697-703.

26. Camacho DP, Gasparetto A, Svidzinski TIE: The effect of chlorhexidine and gentian violet on the adherence of Candida spp. to urinary catheters. Mycopathologia 2007, 163:261-266.

27. Hawser SP, Dauglas LJ: Biofilm formation by Candida species on the surface of catheter materials in vitro. Infect Immun 1994, 62:915-921.

28. Shinde RB, Raut JS, Karuppayil SM: Biofilm formation by Candida albicans on various prosthetic materials and its fluconazole sensitivity: a kinetic study. Mycoscience 2011, 53:220-226.

29. Christie MS, Kenneth LR, David BW: Assessing toxicity of fine and nanoparticles: comparing in vitro measurements to in vivo pulmonary toxicity profiles. Toxicological Sci 2007, 97(1):163-80.

30. De Quadros AU, Bini D, Pereira PAT, Moroni EG, Monteiro MC: Antifungal activity of some cyclooxygenase inhibitors on Candida albicans : PGE2-dependent mechanism. Folia Microbiol 2011, 56:349-352.

31. Deva R, Sczepanski M, Saha S, Zafiriou MP, Kerstin N, Jakobsson PJ, Inoue Y, Nigam S: C. albicans activates cyclooxygenase but not its product prostaglandin $E_{2}$ in HPV 16-stabilized cells. Eur J Obstet Gynecol Reprod Biol 2010, 152(2):205-209.

32. Shareck J, Belhumeur P: Modulation of morphogenesis in Candida albicans by various small molecules. Eukayo Cell 2011, 10(8):1004-1012.

33. Momin RA, De Witt DL, Nair MG: Inhibition of cyclooxygenase (COX) enzymes by compounds from Daucus carota L. Seeds. Phytother Res 2003, 17:976-979.

34. Rajput SB, Karuppayil SM: $\beta$-asarone, an active principle of Acorus calamus rhizome, inhibits morphogenesis, biofilm formation and ergosterol biosynthesis in Candida albicans. Phytomed 2013, 20:139-142.

doi:10.1186/1749-8546-8-18

Cite this article as: Rajput et al:: Anti-Candida properties of asaronaldehyde of Acorus gramineus rhizome and three structural isomers. Chinese Medicine 2013 8:18.

\section{Submit your next manuscript to BioMed Central and take full advantage of:}

- Convenient online submission

- Thorough peer review

- No space constraints or color figure charges

- Immediate publication on acceptance

- Inclusion in PubMed, CAS, Scopus and Google Scholar

- Research which is freely available for redistribution 